\title{
A REVIEW OF THE COMPLICATIONS OF SPINAL ANAESTHESIA WITH EXPERIENCES IN CANADIAN TEACHING HOSPITALS FROM 1959 TO $1969^{\circ}$
}

\author{
A. B. Noble, M.D., F.H.C.P.(C) ANd J. G. Murkay, M.D., C.R.C.P.(C) †
}

As WE ENTER A NEW DECADE it is interesting to think retrospectively and consider the changes we have witnessed. Anaesthesia is becoming a clinical science. We attempt to train our younger men to be selective in the methods best adapted to meet a wide variety of clinical situations. The modern practitioner is less prone to be influenced by habit, personal preferences and expediency. Progress of this type demands a continuing reappraisal of both methods and agents.

Spinal anaesthesia is one of the older techniques in our armamentarium. Since first introduced some sixty years ago, the record has been turbulent at times. A massive bibliography is now available and it can be condensed into an interesting history. Many have contributed to improvements in safety and in decreasing the factors responsible for morbidity. Others have introduced alternative conduction methods in an attempt to avoid some of the complications of spinal anaesthesia. It is important to establish an objective appraisal as a result of current knowledge. Composite experience should enable us to decide whether or not spinal anaesthesia deserves a continuing and recognized place in the armamentarium of younger men being prepared for careers as anaesthetists.

Historically, spinal anaesthesia was introduced by Bier in 1898. It was ten years later that Mr. Barker, ${ }^{1}$ a British surgeon, presented a paper to the Section of Pharmacology and Therapeutics of the British Medical Association. This was the forum for all topics on anaesthesia at that time. He described the findings following performance of lumbar puncture on nine patients two days after the administration of intraspinal Stovaine. He reported the spinal fluid to be turbid due to pleocytosis. These findings substantiated the clinical manifestations of meningeal irritation which were encountered. This was one of the first reports of what was probably a chemical irritation produced by a local anaesthetic agent injected intraspinally.

The method continued to be used for another ten years before another and more dramatic hazard began to appear. Respiratory arrest resulting from total spinal anaesthesia began to be reported as the responsible factor in many anaesthetic deaths in the early 1920s. This is now a completely preventable complication, and if it does occur we can prevent serious sequelae by artificially supporting respiratory function. However, in those days the situation was different and in 1929 an article appeared by Sise, ${ }^{2}$ who wrote as follows: "During the past year when spinal anaesthesia has enjoyed a great wave of popularity, there have

"A presentation to the British Columbia Division of the Canadian Anaesthetists' Society, Vancouver, 26 February 1970.

†Department of Anaesthesia, Sunnybrook Hospital, University of Toronto. 
occurred in Greater Boston at least eleven deaths which are directly traceable to its use. The death rate has not been much better than one in one hundred. This seems excessively high." In this article Dr. Sise records a personal case of respiratory and cardiac arrest. The patient was resuscitated but died two days later. Dr. Sise attributed death to the effects of anoxia on the delicate nerve cells of the brain. The details of this pathological process as a possible complication of spinal anaesthesia were later confirmed by Courville. ${ }^{3}$ Sise was subsequently responsible for devising a hyperbaric technique to control spinal anaesthetic levels and this most reliable method is in common use today. This same problem was investigated independently by $\mathrm{Mr}$. Etherington-Wilson, ${ }^{4}$ a British surgeon, who utilized a hypobaric solution (Percaine 1:1500) and described his technique of "timed vertical ascent." This he confirmed by the injection of coloured hypobaric solutions into glass models of the spinal canal filled with isobaric saline and timing the rate of ascent of the coloured solution. His methods were not exact and there were many variables affecting the rate at which the solution diffused. In clinical practice there was no anatomical barrier to avoid involvement of the vital medullary centres. His papers were obviously subjected to considerable criticism because in his writings he displays annoyance with the prejudices of his readers. Despite many valid criticisms, however, his technique remained in use in certain centres in Great Britain and Canada until the 1950s. It was most definitely not a controllable method.

Modern methods of controlling spinal anaesthesia are effective and serious complications will not occur in trained hands. Probably the most common cause of total spinal anaesthesia today is the inadvertent accidental intraspinal injection of a large volume of local anaesthetic solution during an attempted epidural anaesthetic. This has recently been confirmed by Moore ${ }^{5}$ from records of 12,386 spinal blocks and 7,286 epidural blocks. His records indicate that a spinal block is safer. One of us ( $\mathrm{ABN}$ ) has been personally responsible for producing total spinal anaesthesia accidentally during an attempted epidural block on two occasions during the past five years and has not had an accident of this type as a complication of spinal anaesthetic since 1943.

It is not the intent to reproduce an academic classification of the complications of spinal anaesthesia. However, it is in order to mention some of the unpleasant types of morbidity that have materially reduced acceptance over the years. The most important of course is post-spinal headache. We are now fully aware that altered spinal fluid dynamics is the responsible mechanism. Control or avoidance of leakage of spinal fluid through the inevitable perforation in the dura has resulted in marked decrease in the incidence of this complication. ${ }^{6}$ Greene ${ }^{9}$ and others have made a major contribution with the introduction of fine 25- and 26-gauge needles some twenty years ago. The technical difficulties of introducing a fine malleable needle can be largely overcome by utilizing a Sise introducer. Many methods have been advocated to control the incidence of post-spinal headaches. These include maintenance of the head down position, oral and parenteral hydration, epidural injections of saline, tight abdominal binders, analgesics, and even vitamin solutions. More recently Gormley and Ozdili have reported on a method of prevention. Following the intraspinal injec- 
tion of the anaesthetic agent, the needle is withdrawn into the epidural space and a second syringe is attached, containing $2.5 \mathrm{ccs}$ of the patient's blood. This is injected into the epidural space and will result in occlusion of the hole in the dura by a fibrin patch. The author records excellent results in over one hundred cases and deserves considerable credit for his originality.

Temporary paralysis of certain cranial nerves, particularly the sixth, have been encountered as a sequel to post-spinal cephalalgia. Our colleagues who are neurologists frequently contend that anaesthetists miss this complication, because it may be of a minor degree and short duration and manifest only by slight diplopia. The abducens nerve, according to Hayman and Wood, ${ }^{10}$ is particularly vulnerable to alterations in spinal fluid pressure because of its long course across the base of the skull and its passage around the petrosal portion of the temporal bone.

Much casual comment has blamed spinal anaesthesia as a frequent cause of postoperative low back pain. The sophisticated diagnostician looking for the unusual, may ascribe it to injury of the intervertebral disc, with injury of the annulus and resultant extrusion of the nucleus pulposus. This is actually a rare cause and most of the confirmed cases have probably been reported in the literature. ${ }^{11}$ Following spinal anaesthesia, areas of tenderness resulting from soft tissue injury are common and many agree that local pain and tenderness may be caused by periosteal perforation resulting from faulty technique. $\mathrm{Cotev}^{12}$ in a recent article on this subject, prefers to ascribe much of this discomfort to ligamentous stretching and joint capsule tension. He does not mention the possibility of reactive spasm of the lumbar and sacral muscles as being of any importance. Actually as we all know, postoperative muscle spasm is common following prolonged surgery under any form of anaesthesia. There is no doubt that the incidence of this complication is much less in the hands of a trained individual who is concerned with preventing it.

The most serious deterrent to the continued use of spinal anaesthesia in the future is the possible occurrence of serious and permanent sequelae resulting from complications affecting the spinal cord and its coverings.

The publications of the eminent neurologist Dr. Foster Kennedy ${ }^{13}$ created a definite impact on this subject. In 1947 and again in 1950 he correlated clinical reports from the literature with some of his personal clinical observations. His personal conclusion was that spinal anaesthesia is a technique associated with many hazards not fully appreciated by anaesthetists and surgeons. His outstanding remark was "Paralysis below the waist is too great a price to pay for the surgeon to have a relaxed field of operation." The reliability of his clinical records was unquestioned and some of the arguments presented by anaesthetists in rebuttal were not impressive. One unfortunate aspect of Dr. Kennedy's article was the lack of details concerning the anaesthetic procedures utilized. We can remember that these writings were generously copied in the lay press and the resultant influence soon became manifest in the form of legal decisions.

At about the same time the famous Wooley and Roe case ${ }^{14}$ materially influenced the reputation of spinal anaesthesia in Great Britain. These two men were operated on in the same room one morning, one for meniscectomy and 
the other for hydrocele. Both received the same form of spinal anaesthesia and both developed painful, permanent paraplegia within a few days. Many contradictory medical opinions were given before the High Court at the subsequent trial. In his judgment the presiding judge expressed the opinion that the most likely cause of damage to the nerve tissue resulted from the contamination of the local anaesthetic solution by the phenol solution in which the ampules were stored for sterilization. It was felt that the contamination had occurred through invisible cracks in the glass ampules. The resultant publicity produced a marked decline in the use of spinal anaesthesia in the United Kingdom and the reasons relate to the fear of clinical complications and the legal implications rather than to scientific fact. Nevertheless, the reaction was reasonable.

It is true that the most serious permanent complications of spinal anaesthesia are those affecting the spinal cord and its coverings, and the most important is chronic adhesive arachnoiditis. This is an inexact process that occurs in several forms, and there are many resultant implications. The pathological process may be insidious and the clinical manifestations may be delayed for weeks or even months. It is essentially a proliferative arachnoidal reaction with later fibrosis and distortion of the subarachnoid space. Numerous fibrous septa may form and cause obstruction and later cyst formation. Segmental obliteration of portions of the subarachnoid space may supervene. Greene ${ }^{15}$ contends that the arachnoidal reaction produces an interference with the blood supply to the cord and the nerve roots within the subarachnoid space. Greenfield and associates ${ }^{16}$ have described a characteristic arteritis which they consider to be responsible for the interference with the blood supply to the arachnoid and to the cord and nerve roots. In some of the lesions described the media was more or less completely replaced by collagen with thinning of the elastica and concentric hypertrophy of the intima. The resultant constriction of the lumen was felt to be responsible for many of the ischaemic changes resulting. It is also significant that in many of the specimens examined, the pathological changes described were more concentrated in the region of the lumbo-sacral enlargement of the spinal cord. This is the area which would be exposed to the highest concentration of the local anaesthetic agent injected intraspinally. Greenfield's opinion is that there has been an irritant introduced into the lumbar cul-de-sac, producing constrictive changes in the intima and media of the meningeal vessels and a later progressive thickening of the pia arachnoid. These lesions do not result from simple lumbar puncture. The nature of the arachnoidal reaction suggests a response to an irritant or toxin, which could be produced by an irritant local anaesthetic agent or a contaminated agent. It is also possible that certain individuals may generate local tissue reactions due to an idiosyncrasy or to an hyper-allergic state.

As mentioned, the region of the cauda equina is the most frequently involved. The resultant effect on autonomic sensory and motor fibres will result in the loss of sphincter control of bladder and bowel, decreased perineal sensation, and varied motor effects on the lower extremities, depending upon the degree of involvement. Courville ${ }^{16}$ describes the so-called cauda equina syndrome in 
detail. In his pathological description of chronic adhesive arachnoiditis, he describes a process of meningeal congestion followed by thickening and ultimate adhesion formation between the pia and the arachnoid. He describes the patchy formation of these adhesions which may form at any level of the cord and states that to him it is obvious that such lesions are the result of chemical irritation.

It seems eminently reasonable to conclude that the complication commonly referred to as aseptic meningitis is simply the result of a reversible meningeal reaction resulting from minor irritants. The clinical manifestations are those of meningeal irritation and the spinal fluid exhibits increased protein and pleocytosis.

Barker's ${ }^{1}$ report on Stovaine was undoubtedly the result of chemical irritation by the spinal anaesthetic agent then in use. Clinical experience and investigation over the years has revealed that some local anaesthetic agents used in spinal anaesthesia are essentially devoid of irritant properties. Tetracaine (Pontocaine) is such an agent. Many of us, having used this agent with complete satisfaction, are extremely hesitant to attempt to use or investigate newer agents because it is difficult to estimate the possible reactions in advance. Some agents, of which Procaine is an example, may be inert in low concentrations and irritate in higher concentrations. For example, a Procaine solution of 3 per cent injected intraspinally may irritate.

Episodes have been traced to foreign particulate matter and old blood in spinal needles, the use of non-pyrogen free distilled water as a cleansing agent for equipment, the rinsing of syringes in detergents which are incompletely removed by washing, and cleansing with phenol containing solutions that cannot be completely removed by washing in water. Intraspinal RISA and Pantopaque have been incriminated. A recent article by DiGiovanni ${ }^{18}$ traced several recent cases in United States Army Hospitals to pyrogen containing dextrose ampules used with the tetracaine.

Following the Wooley and Roe case, Rendell ${ }^{21}$ found evidence of pleocytosis and increased protein in nine patients who were given spinal anaesthetics from syringes stored in Lysol solution. These changes were not observed in five patients who were given similar anaesthetics from syringes which were Lysol free.

Hurst $^{22}$ studied the effects of intrathecal detergents in monkeys, using several substances. He concluded that the reaction would occur only following the introduction of very high concentrations.

Joseph $^{23}$ induced spinal anaesthesia in eighteen monkeys, nine of which received anaesthesia from syringes washed in detergent solutions and not subsequently rinsed. Seven of the animals showed evidence of arachnoiditis when sacrificed three to fourteen months later. Two had severe reactions and one animal was paraplegic.

Denson and Joseph ${ }^{24}$ in a similar study found marked species differences and discontinued using dogs because of the extreme meningeal reaction that occurred in that animal following the introduction of test substances. They continued with monkeys, inducing spinal anaesthesia with syringes soaked in detergents, 
sterilized and not washed. Some received more than one injection. Without quoting details, later examination of the spinal cord and meninges revealed gross involvement of the pia and arachnoid in all cases.

It is obvious that the utmost care is indicated in the preparation of the patient and the sterilization and cleansing of needles and syringes. Needles, syringes, gloves, and ampules must all be dry and alcohol free.

As mentioned before, DiGiovanni ${ }^{18}$ has made a contribution with regard to the possibility of pyrogen contamination. He points out that pyrogens are ether soluble and his investigations suggest that disposable sets are less hazardous than reusable spinal needles and syringes.

Septic meningitis is a rare and preventable complication. The casual approach to aseptic technique is not good enough when applied to spinal anaesthesia. The recent literature records one instance of accidental contamination occurring as a result of defective Berkefeldt filter on the intake system of the water supply in the operating rooms of a Sheffield hospital. ${ }^{20}$ The result was the occurrence of eleven cases of meningitis following spinal anaesthesia.

Spinal or epidural needles are obvious potential causes of direct injury to the spinal cord. The fine needles used in spinal anaesthesia rarely cause injury when properly introduced below the filum terminale. The nerve roots are well protected as they float in a fluid medium. Paraesthesiae caused by light contact with these nerves seldom cause post-anaesthetic discomfort. The spinal nerves are relatively fixed at the intervertebral foramina and an incompetent person can injure the nerve roots at this point. Complications of this nature are rare. It is impossible to obtain valid information concerning the incidence of direct injury to the cord and the nerve roots. However, the anatomical implications are definite and these complications are preventable by restricting lumbar puncture to a point below the second lumbar interspace.

Moore $^{19}$ rightly warns of the increased hazards associated with thoracic and cervical epidural injections using larger Tuohy needles. Trauma to the cord by any means may be complicated by aseptic meningeal reactions resulting from the presence of extravasated blood.

In completing this part of our discussion we must refer to certain rare occurrences affecting the spinal cord. Acute degeneration of the central grey matter and peripheral necrosis resulting from conditions affecting the anterior spinal artery have been reported. Courville ${ }^{17}$ recorded a case of acute softening of the central grey matter of the cord in a patient operated on under spinal anaesthesia while in shock. Paraplegia preceded death ten days later. The central necrosis of the cord was attributed to ischaemia resulting from vasomotor changes compromising the circulation to the cord. Some cases have been reported in which the lesion found at post mortem was a peripheral necrosis of the anterior portion of the spinal cord. The anterior spinal artery is an end artery and the aetiology was ascribed to a period of hypotension in patients suffering from arteriosclerotic changes in the anterior spinal artery, resulting in irreversible ischaemic damage. This complication has been ascribed to the hypotensive state that might occur during spinal anaesthesia. However, Urquhart- 
Hay $^{25}$ has reported a case occurring under epidural anaesthesia, and the same mechanism has also been recorded under general anaesthesia.

At this point it is interesting to note that many of the potential problems discussed as complications of spinal anaesthesia, can and do occur with epidural techniques.

\section{Conditions which may Simulate Complications of Spinal Anaesthesia}

While recognizing the fact that genuine complications of spinal anaesthesia do occur, it should be emphasized that genuine neurological sequelae of spinal anaesthesia are extremely rare. Scarborough ${ }^{26}$ in reporting 65,677 cases of patients receiving spinal anaesthesia, found the overall incidence of complications to be less than 0.18 per cent. These included transient complaints of weakness and paraesthesias of the lower extremities, but no paraplegias were recorded. The extensive studies of Dripps and Vandam ${ }^{27,28}$ and Sadove, Levin, and Rant-Sejdinaj ${ }^{29}$ have also demonstrated that the actual incidence of neurological complications following spinal anaesthesia is considerably less than formerly supposed.

Those neurological manifestations which coincide with, but are unrelated to, the spinal anaesthetic, are important because they lead to confusion in respect to the actual incidence and pathogenesis of those disorders which are actually due to the spinal anaesthetic itself. As Greene ${ }^{15}$ has pointed out, "the failure to recognize the fortuitous nature of these conditions by consultants who are either biased or unacquainted with modern anaesthetic techniques, has led to unnecessary confusion."

Marinacci ${ }^{30}$ in an extensive investigation of 542 patients with symptomatology suggesting the possibility of a complication of spinal anaesthesia, was able to demonstrate conclusively that in only four patients of this group could the neuropathy be blamed on the spinal anaesthetic. In the remaining 538 patients the symptoms were due to some concurrent but unrelated simulator.

Leatherdale $^{31}$ in reporting a case of spinal anaesthesia with unrelated paraplegia, has emphasized the necessity of most careful investigation when such a complication does arise, before making a categorical statement that the spinal anaesthetic is to blame. Since Ciliberti ${ }^{32}$ in 1948 reported a case of paraplegia following inhalation anaesthesia, further case reports of paraplegia and neurological disturbances following anaesthesia other than spinal, have appeared in the literature. Gilbert ${ }^{6}$ has mentioned a case of apparent post-spinal paraplegia (and so labelled it), which proved on further investigation to be due to hysteria, as the chart bore witness to the fact that the patient had received a general anaesthetic.

Those conditions, which may simulate a genuine complication of spinal anaesthesia and are frequently attributed to it, may be conveniently divided into the following groups.

(1) Aetiological factors existing prior to the administration of the spinal anaesthetic. These include progressive spinal muscular atrophy, spinal cord 
tumor, pre-existing radiculopathy, peripheral neuritis and subclinical myotonia. These disorders are composed of pre-existing neurological diseases which would progress naturally to manifest symptomatology, their course being essentially unaltered by the administration of the spinal anaesthetic. The frequent appearance of spinal cord meningiomas in association with spinal anaesthesia is an example of this group. ${ }^{15}$

(2) Conditions occurring concurrently with the administration of a spinal anaesthetic. These include hysterical paralyses; nerve injuries resulting from surgical trauma or posture during operation. Nerve injuries resulting from intramuscular injections are rare, but do occur. ${ }^{30}$ An article by Ruston and Politi ${ }^{33}$ reporting three cases of femoral nerve paralysis from surgical retraction during pelvic surgery, one of which was bilateral, illustrates the ease with which such neurological manifestations could be confused with sequelae of a spinal anaesthetic.

(3) Neurological complications developing during the post-spinal period, precipitated by systemic diseases or trauma. These include the peripheral neuropathies, both mechanical and toxic, as well as the neuro-depressant effects of such antibiotics as Neomycin and Colymycin. ${ }^{34}$ Alcoholic polyneuritis, and pressure neuropathies in the postoperative period of convalescence are documented by Marinacci ${ }^{30}$ as having been mistaken for post-spinal neurological sequelae.

(4) Other causes. These include Porphyria of which one of the chief manifestations is a neuropathy of the lower extremities. If the abdominal distress from acute toxic porphyria should result in surgical exploration under spinal anaesthesia, the resultant neurological manifestations might present a misleading picture.

Infectious Neuronitis has proved to be one of the most troublesome simulators of the complications of spinal anaesthesia, as the cauda equina is usually the area involved.

Horse serum plexitis, anaphylaxis due to blood transfusions, and drug neuropathies such as that due to Isoniazid may all result in a clinical picture which imitates a complication of spinal anaesthesia. ${ }^{30}$

As soon as signs or symptoms appear, the first step should be a complete neurological evaluation of the patient, this being followed by a diagnostic lumbar puncture, even though the information so obtained may be only of negative value. Myelography should be undertaken only cautiously because of its mild inflammatory propensities in cases of arachnoiditis. ${ }^{15}$

The single most important means of establishing the diagnosis has proved to be the electromyogram, ${ }^{35}$ which will demonstrate the fibrillation potentials of denervated muscle fibres after a period of fourteen to twenty-one days. Such electrical activity as demonstrated by the electromyogram is pathognomonic of lower motor neuron injury; it is not seen in upper motor neuron lesions or in primary muscle disease.

Differentiation of a complication of spinal anaesthesia and a condition which clinically simulates it is based upon two basic elements; (1) the distribution of the denervation, and (2) the time in which the denervation is detected 
TABLE I

\begin{tabular}{|c|c|c|c|}
\hline Hospital & University & No, of cases & Complications \\
\hline Sunnybrook Hospita! & University of Toronto & 974 & None serious \\
\hline $\begin{array}{l}\text { Toronto General } \\
\text { Hospital }\end{array}$ & Eniversity of Toronto & 800 & None serious \\
\hline $\begin{array}{l}\text { Toronto East General } \\
\text { Hospital }\end{array}$ & University of Toronto & 752 & None serious \\
\hline St. Michael's Hospital & Lniversity of Toronto & 3,453 (7 yr) & None serious \\
\hline $\begin{array}{l}\text { Toronto Western } \\
\text { Hospital }\end{array}$ & Lniversity of Toronto & 351 (5 yr) & None serious \\
\hline $\begin{array}{l}\text { Women's College } \\
\text { Hospital }\end{array}$ & University of Toronto & 151 & None serious \\
\hline Westminster Hospital & $\begin{array}{l}\text { Cniversity of Western } \\
\text { Ontario, London, Ont. }\end{array}$ & $1,091(6 \mathrm{yr})$ & None serious \\
\hline St. Joseph's Hospital & $\begin{array}{l}\text { University of Western } \\
\text { Ontario }\end{array}$ & ${ }^{660}(5 y r)$ & None serious \\
\hline $\begin{array}{l}\text { Kingston General } \\
\text { Hospital }\end{array}$ & $\begin{array}{l}\text { Queen's Lniversity } \\
\text { Kingston }\end{array}$ & 391 (9 yr) & $\begin{array}{l}1 \text { death cardiac arrest } \\
\text { (86 yr fem. fract. hip- } \\
\text { blood loss) }\end{array}$ \\
\hline Hotel Dieu & Queen's University & 1,012 & None serious \\
\hline Ottawa Civic Hospital & University of Ottawa & 1,010 & None serious \\
\hline Maisonneuve Hospital & University of Montreal & 4,834 & $\begin{array}{l}1 \text { post-op. headache } \\
4 \text { dys foll. by transit. } \\
\text { abducens nerve par. } \\
2-3 \text { months }\end{array}$ \\
\hline Hotel Dieu & University of Montreal & $3,823(9 \mathrm{yr})$ & None serious \\
\hline $\begin{array}{l}\text { Montreal General } \\
\text { Hospital }\end{array}$ & McGill University & 1,642 & None serious \\
\hline $\begin{array}{l}\text { Queen Mary Veterans } \\
\text { Hospital }\end{array}$ & $\begin{array}{l}\text { McGill University } \\
\text { University of Montreal }\end{array}$ & 1,620 & None serious \\
\hline St. Mary's Hospital & McGill University & 343 & None serious \\
\hline Royal Victoria Hospital & McGill University & 4,261 & None serious \\
\hline L'Hotel Dieu de Quebec & $\begin{array}{l}\text { Laval University } \\
\text { Quebec City }\end{array}$ & 3,202 & None serious \\
\hline Halifax Infirmary & Dalhousie University & 315 & $\begin{array}{l}1 \text { myocard. infarct } \\
30 \text { hrs after TUR P. } \\
(84 \text { yrs) }\end{array}$ \\
\hline $\begin{array}{l}\text { Victoria General } \\
\text { Hospital }\end{array}$ & Dalhousie University & 2,156 & 1 doubtful \\
\hline $\begin{array}{l}\text { St. Boniface General } \\
\text { Hospital }\end{array}$ & $\begin{array}{l}\text { University of } \\
\text { Manitoba, Winnipeg }\end{array}$ & 4,515 & 1 related death \\
\hline $\begin{array}{l}\text { Winnipeg General } \\
\text { Hospital }\end{array}$ & $\begin{array}{l}\text { University of } \\
\text { Manitoba }\end{array}$ & 4,493 & None serious \\
\hline University Hospital & $\begin{array}{l}\text { Lniversity of } \\
\text { Saskatchewan, Saskatoon }\end{array}$ & 1,451 & None serious \\
\hline University Hospital & $\begin{array}{l}\text { University of Alberta } \\
\text { Edmonton }\end{array}$ & 6,509 & None serious \\
\hline $\begin{array}{l}\text { Royal Alexandra } \\
\text { Hospital }\end{array}$ & $\begin{array}{l}\text { Lniversity of Alberta } \\
\text { Edmonton }\end{array}$ & 2,145 & $\begin{array}{l}1 \text { footdrop (pain) } \\
\text { temporary }\end{array}$ \\
\hline $\begin{array}{l}\text { Vancouver General } \\
\text { Hospital }\end{array}$ & $\begin{array}{l}\text { University of } \\
\text { British Columbia }\end{array}$ & 17,612 & $\begin{array}{l}1 \mathrm{~L}-4 \text { root damage-- } \\
\text { recovered }\end{array}$ \\
\hline \multirow[t]{2}{*}{ Shaughnessy Hospital } & $\begin{array}{l}\text { University of } \\
\text { British Columbia }\end{array}$ & 9,180 & None serious \\
\hline & Total no. & 78,746 & \\
\hline
\end{tabular}


electromyographically. In a true complication of spinal anaesthesia the denervation activity will not be detected until three weeks after the administration of the anaesthetic, and the distribution of fibrillatory potentials in a true case of cauda equina radiculopathy will be restricted to the paraspinal muscles, the pelvic girdle and the muscles of the lower extremities.

\section{Experience in Canadian Teaching Hospitals}

A survey of twenty-seven Canadian University affiliated hospitals has revealed a total of 78,746 spinal anaesthetics administered during the past ten years. (Table I) In this series, no deaths occurred which were attributable to spinal anaesthesia. The method has been recorded as a contributory cause of cardiac arrest in three cases.

No serious permanent complications have been encountered.

Two cases of neuropathy affecting lumbar segments and one abducens nerve paralysis occurred. All recovered within a period of three months.

The survey revealed that anaesthetists are becoming more selective in the use of spinal anaesthesia. In the majority of instances it is used for surgical procedures below the umbilicus.

Recent experiences indicate a definite reduction in the mortality and morbidity resulting from this method, and the hazards are now no greater than with any other technique used in anaesthesia.

Spinal anaesthesia should be retained as a part of the armentarium of the anaesthetist.

\section{RÉSUMÉ}

Pendant nos recherches sur cet intéressant sujet, il devint évident qu'on avait ajouté très peu de choses au point de vue scientifique à la réputation de l'anesthésie rachidienne depuis l'apport considérable de Dripps et Vandam, Sadove et Greene il y a une dizaine d'années.

Il a été suggéré que l’atmosphère des hôpitaux canadiens d'enseignement pourrait apporter des opinions et des renseignements pratiques. Le champ n'est pas trop vaste et les rencontres sont fréquentes entre les anesthésistes des hôpitaux canadiens d'enseignement. Ces départements sont relativement stables quant au personnel et dans ces hôpitaux des consultations entre les différentes disciplines sont fréquentes et constructives. Nous étions d'avis que nous pouvions facilement obtenir une coopération raisonnable, pourvu qu'on n'ait pas besoin d'enquêtes personnelles laborieuses impliquant de nombreux dossiers d'hôpital. Les genres de renseignements requis concernaient les complications graves dont on retiendrait la fréquence. On a admis que le nombre de complications survenues dans des hôpitaux de banlieu et référées aux centres neurologiques ne pourrait pas être obtenu avec précision, et nous reconnaissons facilement qu'il y a d'autres causes d'inexactitude dans les renseignements obtenus. Il y a des objections à une enquête rétrospective de ce genre et ces inexactitudes possibles ont été bien décrites par Greene.

Nos demandes de renseignements ont reçu une excellente réponse de vingt 
sept institutions sur les vingt-neuf visitées. Nous avons exclu les hôpitaux récemment construits où nous ne pouvions par avoir de dossiers pour une période de dix ans. La plus grande difficulté recontrée fut que certains hôpitaux avaient récemment installé le système de cerveaux électroniques. Dans ces hôpitaux, les dossiers obtenus avant linstallation de ces récents appareils étaient la plupart du temps inaccessibles ou inutiles.

Les réponses ont couvert un total de 78,746 anesthésies rachidiennes pour la période de 1959 à 1969 inclusivement.

La somme des complications se lit comme suit:

Un cas de céphalée grave ayant duré cinq jours, compliquée d'une paralysie des nerfs abducteurs guérie au bout de 8 à 10 semaines.

Un cas de paralysie du nerf périnéal a été attribué à l'anesthésie rachidienne. Le malade guérit en trois mois.

Un cas de radiculite affectant la quatrième racine lombaire. Guérison complète en dix semaines.

Quelques commentaires fournis par les correspondants présentaient un intérêt particulier.

(1) Quatre correspondants ont émis l'opinion que l'anesthésie rachidienne présente un intérêt particulier pour certains cas choisis, surtout pour des opérations au-dessous de lombilic. Ces dernières comprennent la résection transurétrale de la prostate, la gynécologie et la proctologie; deux ont prétendu qu'ils préfèrent cette anesthésie pour les cas de césarienne, sauf bien entendu en cas de contr'indications bien définies.

(2) Un hôpital a signifié sa préférence pour l'anesthésie épidurale à dose unique pour la plupart des cas d'obstétrique. Ils ont enregistré 127 cas de rachi accidentelles au cours de tentatives d'épidurales durant ces dix années.

(3) Trois départements ont enregistré chacun un décès pour lequel, à leur avis, l'anesthésie rachidienne a été un important facteur contribuant. Ces cas étaient tous semblables. Il s'agissait d'anesthésies rachidiennes pratiquées pour enclouage de la hanche chez des malades débiles, artérioscléreux qui ont présenté une hypotension immédiate et un arrêt cardiaque peu après l'administration de l'anesthésique. Aucun n’a pu être réanimé. A l'autopsie, un malade avait des signes évidents d'un infarctus récent du myocarde.

(4) Un hôpital de l'Ontario a déclaré qu'il n'y avait pas eu un cas de paraplégie après une anesthésie rachidienne depuis 1947; à cette époque les ampoules étaient conservées dans des solutions antiseptiques colorées.

(5) Un correspondant a maintenu que cette anesthésie est définitivement indiquée pour les transplantations rénales. Ces cas sont généralement amenés à la salle d'opération à l'improviste, ils ont souvent l'estomac rempli et les malades souffrant généralement d'anémie et d'hyperkaliémie. L'épidurale continue et la rachi continue ont toutes deux été utilisées dans cette institution, mais après des années d'expérience leur préférence va à la rachidienne continue.

L'anesthésie rachidienne n'est plus utilisée de préférence pour la chirurgie abdominale. Plusieurs correspondants reconnaissent que l'anesthésie rachidienne n’est plus utilisée que pour des cas choisis et sa fréquence varie de 0 à 5 pour cent de toutes les anesthésies. Il semble que la fréquence moyenne se situe aux 
environs de 3 pour cent. Un hôpital a enregistré une baisse graduelle de la rachi jusqu'en 1968; sur un total de 8500 anesthésies, aucune rachidienne n'a été pratiquée.

\section{REFERENCES}

1. BARker, A. E. Elimination of Stovaine after Spinal Anaesthesia. Br. Med. Jr. 2:789 (1909).

2. Sise, L. F. Spinal Anaesthesia, Fatalities and their Prevention. New England Jr. of Med. 200:21:107 (1929).

3. Covrville, C. B. Case Studies in Cerebral Anoxia iII, Structural Changes in the Brain after Cardiac standstill under Spinal Anaesthesia. Bulletin Los Angeles Neurol. Soc. 19:142-150 (1954).

4. Etherington-Wilson, W. Specific Gravity of the Cerebrospinal fluid with special reference to Spinal Anaesthesia. Br. Med. Jr. 165 (1943).

5. Moone, D. C. et al. The Present Status of Spinal and Epidural Block. Anaesthesia \& Analgesia, Current Researches, 47: 1:40-49 (1968).

6. Gilbert, R. G. Neurological Complications of Spinal Anaesthesia. Cdn. An. Soc. Jr. $2: 2: 116(1955)$.

7. OzDIL, T. \& Powell, W. F. Post lumbar puncture headache. Anaesthesia \& Analgesia, Current Researches, 44:511-542 (1965).

8. Gormley, J. B. Treatment of post spinal headache. Anaesthesiology. 21:5:565 (1960).

9. Greene, B. A. A 26-gauge Lumbar Puncture needel - its value in prophylaxis of Headache following Spinal Anaesthesia for Vaginal delivery. Anaesthesiology. 11:464 (1950).

10. Hayman, I. R. \& Wood, P. M. Abducens Nerve Paralysis following Spinal Anaesthesia. Annals of Surgery. 115:5:864 (1942).

11. Epps, P. G. A Case of Degeneration of the Intervertebral Disc following Lumbar Puncture. Proc. Royal Soc. Med. 35:220 (1942).

12. Cotex, S. et al. Back pain after Epidural Anaesthesia. Anaesthesia \& Analgesia, Current Researches. 46:2:259 (1967).

13. Kennedy, Foster et al. The Grave Spinal cord paralyses caused by Spinal Anaesthesia. Surgery, Gynecology \& Obstetrics. 91:4:385 (1950).

14. Walshe, F. quoted by Cope, R. W.; "The Wooley \& Roe Case". Anaesthesia. 9:249 (1954).

15. Greene, N. M. Neurological Sequelae of Spinal Anaesthesia. Anaesthesiology. 22:5:682 (1961).

16. Greenfield, J.; Richards, A.; \& Manning, G. The Pathology of Paraplegia occurring as a delayed sequelae of Spinal Anaesthesia, with special reference to the Vascular Changes. J. Path. \& Bact. LxIx: 95 (1955).

17. Courville, C. B. Untoward effects of Spinal Anaesthesia on the Spinal Cord and its Investments. Anaesth. \& Analgesia, Current Researches. 34:6:313 (1955).

18. DiGrovanni, A. J. Chemical Meningitis - Personal Experience \& Review of the Literature.

19. Moore, D. C. Epidermal Anaesthesia, Complications of Regional Anaesthesia. Charles C. Thomas Publisher (1965).

20. BarRy, H. I. Meningitis following Spinal Anaesthesia. Lancet. p. 242-243 (1941).

21. Rendell, C. M. Chemical Meningitis due to Syringes stored in Lysol. Anaesthesia. $9: 281(1954)$.

22. Hurst, E. W. Adhesive Arachnoiditis and Vascular Blockage caused by detergents and other chemical irritants. J. Path. \& Bact. 70:165 (1955).

23. Joseph, S. J. \& Denson, J. S. Spinal Anaesthesia, Arachnoiditis and Paraplegia. J.A.M.A. 168:10:1330 (1958).

24. Denson, J. S. et al. Effects of Detergents Intrathecally. Anaesthesiology. 18:1:143 (1957).

25. D'Urquhart-Hay. Paraplegia following Epidural Anaesthesia. Anaesthesia. 24:3:461 (1969).

26. Scarbonough, R. A. Spinal Anaesthesia from the Surgeon's standpoint. J.A.M.A. 168: 1324 (1959).

27. Dripps, R. D. \& Vandam, L. D. Long term follow-up of patients who received 10,098 Spinal Anaesthetics. J.A.M.A. 156:1486 (1954).

28. VANDAM, L. D. \& DrIPPs, R. D. Long term follow-up of patients who received 10,098 spinal anaesthetics. rv, J.A.M.A. 172:1483 (1960). 
29. Sadove, M. S.; Levin, M. J.; \& Rant-SejdinaJ, I. Neurological Complications of Spinal Anaesthesia. C.A.S.J. 8:4 (1961).

30. Marinacci, A. A. Neurological Aspects of Complications of Spinal Anaesthesia. Bulletin Los Angeles Neurological Soc. 24:170 (1960).

31. Leatherdale, R. A. L. Spinal Analgesia and unrelated Paraplegia. Anaesthesia. 14:274 (1959).

32. Cilmberti, B. J. Paraplegia following Inhalation Anaesthesia for Subtotal Gastrectomy. Anaesthesiology. 9:439 (1948).

33. Ruston, F. G., \& Politi, V. L. Femoral Nerve Injury from Abdominal Retractors. C.A.S.J. 5 (1958).

34. Prevoznik, S. J. Truncal Ataxia as a complication of Colistin Therapy: Its relation to Spinal Anaesthesia. Anaesthesia and Analgesia. 46:1 (1967).

35. Marinacci, A. A. \& Courville, C. B. Electromyogram in Evaluation of Neurological Complications of Spinal Anaesthesia. J.A.M.A. 168:1337 (1958). 